\title{
Impact of Gender on Emotional Intelligence of University Teachers in Peshawar, Khyber Pakhtunkhwa
}

\author{
* Dr. Shazia Kanwal, Principal \\ ** Dr. Hafiz Inam, Professor \\ *** Dr. Farooq Nawaz Khan, Assistant Professor (Corresponding Author)
}

\begin{abstract}
There are some stereotypical roles, characteristics, and traits associated with different genders. All genders are being linked with certain emotional states. In the context of the Pakistani scenario which is considered as a patriarchal society, the male gender is regarded as a dominant being and has certain traits like strength, confidence, decision making, and power connected with this gender. Conventionally, the female gender is considered to be very emotional, sensitive, lack confidence and decision making skills. The present study focuses on to find out the existing ground realities, if these gender connected traits have any kind of effect on their performance and effectiveness at workplaces. The proposed research purpose is to investigate the effect of gender on teacher's emotional intelligence at higher educational institutions of district Peshawar. The researcher selected three public universities of Peshawar, Khyber Pakhtunkhwa using cluster sampling technique and using stratified sampling technique SRMEI was administered proportionally to the selected university teachers (female $=59$, male $=106$ ) to assess their emotional intelligence. SRMEI comprises three subscales: emotional self-awareness, emotional self-regulation, and interpersonal relationship. Data was analyzed on SPSS version 20 software. The researcher applied a T-Test to investigate the effect of gender on the EI skills of teachers. The study discovered a fact that teachers' (female gender) mean score $(M=3.71, S D=.212)$ was significantly higher than that of male $(M=2.38, S D=.455)$ on a factor only i.e. interpersonal skills. While both gender groups display similar results on the remaining two facets of Emotional Intelligence (EI) was concerned.

Keywords: Emotional Intelligence (EI), Self-report Measure of Emotional Intelligence (SRMEI), Emotional Self-awareness (ESAS), Emotional Self-regulation (ESRS), Interpersonal Relations (ISS), Teacher Gender

\section{Operational definition of variables}

\section{Emotional Intelligence}

EI is explained as individuals' capacity to identify, comprehend, recognize and communicate emotions in a meaningful, creative and healthy manner.

\section{Gender}

The proposed research defined teachers' gender with male and female categories only.

\section{Introduction}

EI is now known as a vital influence on varied areas of our lives (Fernández-Berrocal, Cabello, Castillo, \& Extremera, 2012). According to Salovey \& Mayer, 1990 EI is a person's ability to comprehend emotional information; and to practice that knowledge for emotional and intellectual growth. EI is "a person's capability to comprehend and handle our emotional state and based on that knowledge-making accurate decisions, while to comprehend feelings of other and managing our relationship with them" (Goleman, 1998, p.317). Since after the recognition of the significance and prominence of the term 'emotional intelligence' (EI), the phenomena has been progressively incorporated initially in the business world and more recently welcomed by educationists and

\footnotetext{
* Elementary and Secondary Education Khyber Pakhtunkhwa Pakistan Email: shaziamd09@gmail.com

** Institute of Education and Research University of Peshawar Khyber Pakhtunkhwa, Pakistan

Email: hafizinam@uop.edu.pk

*** Centre for Education and Staff Training University of Swat Khyber Pakhtunkhwa, Pakistan

Email: farooqlit76@gmail.com
} 
educational institutions. There is an increasing research outcomes that scientifically proves that emotional intelligence is the best predictor of our performance at home, school and at our workplaces" (Reuven Bar-On, 2004). Only 20\% of life success is dependent on cognitive intelligence while the remaining $80 \%$ is attributed to the Emotional Intelligence of an individual (Nelson and Low, 2003 \& Bar-On, 2011). EI skills are strongly allied with effective leadership skills, well-being, and performance at the workplace. IQ is not the only predictor to forecast effective performance, but effective performance and success in professional life depends heavily on Emotional intelligence (Goleman, 1998; Stein, 2013; Bar On, 2001; Cotzee \& Jansen, 2007).

Teaching is a field that involves human beings, and human beings always come up with emotions and feelings. According to GU and Day (2007), Teachers not only come up with "head (cognition)" but with their "heart (emotion)". Though professional success is now to a great extent based on EI skills unfortunately we value head and devalue heart (Singh, 2015). Teaching is a profession, which requires him to perform several roles at the same time (David \& Wilson, 2000). Their profession requires them to be in constant contact with students, colleagues, and administration, so they are required to manage and understand their emotions while developing healthy relations with all these stakeholders. To perform all these roles, a teacher must be emotionally intelligent (Kim, 2002). Viin, Juust, and Tooman (2010), consider the knowledge of emotional intelligence as a basic requirement of effective and successful teaching. Bay and McKeage (2006), also linked Teachers' emotional intelligence with their effective performance including classroom management, healthy interpersonal relations in the classroom, and healthy decision-making abilities. Hassan et al. (2015) were also of the view that the emotional intelligence of educators prompts high job fulfillment and achievement in their professional lives. Teaching is an art that requires intense emotional labor (Hargreaves, 1998). So effective and successful teaching is not only about the delivery of knowledge and pedagogical skills but it requires the teacher to be an emotionally literate person (Hargreaves, 1998).

Although enormous researches have been done to explore the effect of gender differences on EI, however, it is impotent to offer an articulate picture of the situation. Industrialization and globalization have changed the needs of society, consequently changed the role of women in industrial and economic development. They are now a significant and considerable part of the work force in our society either they are working in fields, offices, entrepreneurship, or teaching, women are engaged side by side with their opposite gender in all workplaces. To compete in all these fields we can notice a tremendous increase in the female enrolment in higher education. This substantial variation plea for the increased number of female teachers to work in higher education. In Pakistan, there were a total of 186 universities in 2017-18, while the total number of teachers working at higher education institutions during 2018-19 was 53.9 million (Pakistan economic survey, 2018-19). Female teachers are working side by side with their male counterparts in prestigious and eminent positions.

Generally, it is believed that women by nature are emotionally very sensitive and feel more, also easily understand or have greater empathy for others, and can present their own emotion in an effective way (Brody \& Hall, 2000). Stubbornly, man in our society is considered to be a symbol of strength and power whose emotional expression is not allowed by our social values. He is rendered as a leading role of a society who can better cope with stressful situations; can change himself according to the changing needs of the situation with more ease and confidence (Montanes, 2004).

Various studies on emotional intelligence reveal that women are more capable to identify their emotions correctly, are more empathetic, and have better interpersonal relations. While some of the studies found men more confident, with a more optimistic approach, flexible, and have better ability to cope with stress. (Kerr et al., 2006). Various researches conducted found women with healthy relationships (Parker, et al., 2004), women can better comprehend and cope with their emotions (Ciarrochi, Chan \& Caputi, 2000), women were found more empathetic, and with enhanced emotional vocabulary (McIntyre, 2010). In general most of the studies didn't reveal any substantial difference between the EI skills of both genders. In Some studies, men were found more empathetic and sensible as most of the women have this trait, while some of the women were found to better cope with stressed conditions just like any strong man can do. Results of a study found men with, better adaptability and emotional regulation skills than their counterpart (Alnabhan, 2008), with improved self-control techniques and strategies (Sánchez-Ruiz,2010), higher stress tolerance (Brown, Kirkcaldy \& Thome, 2000), and higher improved relationship and better stress management (Wessell, et al., 
2008). Anuradha and Kalapriya (2015) in their study found a major difference between Emotional Intelligence skills of both genders, they found women possess higher emotional intelligence than men. While there are studies that concluded that gender does not have an impact on EI level (Tiwari \& Srivastava, 2004; Kar et al., 2014). This effect may be the result of cultural and societal influences and expectations from the female gender (Naghavi \& Reduzan, 2011). During Childs' socialization process all the stakeholders, involved in this process i.e. school, friends, family, and media, reassure and inspire women to be more supportive, compliant, communicative, well-adjusted, and in harmony with their relationships (Petrides \& Furnham, 2006). As noted by Petrides and Furnham (2000), during this socialization process some traits are considered more masculine while some are more feminine. Aggressiveness is attributed as a male characteristic while empathy is a female trait (Siegling, Furnham, \& Petrides, 2015). Consequently, these two genders are socialized inversely (Duckelt \& Raffali, 1989; Sandhu \& Mehrotra, 1999). Females are acknowledged to have enhanced EI skills (Singh, 2002; Ryff, Singer, Wing \& Love, 2001).

The variance between males and females EI is inconsistent globally. Van Rooy, Alonso, and Viswesvaran, (2005) found female with better EI and interactive skills than male counterpart. A study conducted in Tamil Nadu, India, also found females with higher EI skills in comparison with male colleagues (Chandra, Gayatri, \& Devi, 2017). A study conducted in Iran found females with enhanced interpersonal skills, and flexibility (Domakani, Mirzaei, \& Zeraatpisheh, 2014). However, numerous studies are stating no clear difference in EI skills of these two genders (Aquino, 2003; Bar-On, 1997; Bar-On, Brown, Kirkcaldy, \& Thome, 2000; Brackett \& Mayer, 2003; Brackett, Rivers, Shiffman, Lerner, \& Salovey, 2006; Brown \& Schutte, 2006; Depape, Hakim-Larson, Voelker, Page, \& Jackson, 2006). Research conducted in Myanmar also discovered no significant difference between the EI of male and female teachers (Myint \& Aung, 2016). While a study conducted in the United Kingdom didn't establish any association between gender and EI of employees (Arteche, ChamorroPremuzic, Furnham \& Crump, 2008).

Some other studies conducted to found the connection between different aspects of EI with gender also displayed varied results. Females were found with greater interpersonal skills (Arteche et al. 2008). Besides, females were found more empathetic and better interpersonal skills (Dunn, 2002; Craig et al., 2009) Females were found better at perceiving and interpreting facial expressions (Kafetsions, 2004). Mayer and Geher (1996), also found women to better display and express their emotions than their male counterparts. Males were found more expressive while displaying negative emotions i.e. aggression (Brody, Hall, and Stokes, 2016). While another study also found males more prone to express highly-intense positive emotions while females are more inclined to display lowintense positive emotions (Else-Quest, Hyde, Goldsmith, \& Van Hulle, 2006; Perry-Parrish \& Zeman, 2011). Females are also found better at understanding emotions but are hesitant in taking decisions (Mayer \& Geher, 1996; Wong \& Law, 2002), while males are more capable at emotional regulation and stress management (Sanchez-Nunez, Fernández-Berrocal, Montanes, \& Lattore, 2008; Nasir and Masrur, 2010). Another EI traits as effective leadership, males revealed more confident leadership skills (Franke, Crown, \& Spake, 1997). A vast number of researches articulate females with enhanced EI skills as compared to their male counterparts, while a minimum number of studies found males with better EI skills than females. Still, researchers do not reach a confident conclusion about the impact of gender on their EI skills. There are different assumptions and results. The use of different EI measuring tools can be one of the reasons, while cultural differences also matter a lot. We can't generalize the results of a study conducted in one culture within the context of any other culture. Some distinguished scholars have conducted researches on the same topic in the Pakistani context as well as researchers in Pakistan have also produced self-developed scales to find out emotional intelligence in their own social and cultural context (Batool \& Khalid, 2011; Dawood, 2007). The researcher in the present study is interested in finding out whether these defined roles of gender have any kind of impact on their work effectiveness. Presently men and women are working parallel to each other in universities with the same qualification and designation, which means they are enjoying the same socio-economic status. In the present study, the researcher wants to assess whether male and female teachers working at the university level display the same strength and weakness in the context of emotional intelligence skills. This research is trying to examine the effects of gender on the emotional intelligence skills of teachers which are linked with teaching effectiveness. The researcher 
hypothesized that there is a significant variation amongst the EI skills of male and female university teachers.

\section{Theoretical framework}

After going through a detailed literature review and studying other research models researcher developed a theoretical model for this study. The present research study is inspired by clusters of emotional intelligence proposed by Goleman's model of emotional intelligence and the EI test SRMEI developed by Kamal (2018). Keeping in view the social and emotional values of people in Pakistan's context the SRMEI (2010) was developed with well-established reliability and validity. SRMEI is comprised of three main facets i.e. emotional self-regulation, emotional self-awareness, and interpersonal skills. The proposed model for the research purpose is to evaluate teachers' emotional competency and to establish the relationship between teachers' gender and their emotional intelligence or emotional competency. Is given below.

\begin{tabular}{|c|c|c|}
\hline EI Dimensions & Competency (SRMEI, 2010) & $\begin{array}{l}\text { Teachers' characteristics required for effective } \\
\text { teaching as a result of EI skills } \\
\text { (Powell and Powell, 2010) }\end{array}$ \\
\hline $\begin{array}{l}\text { Emotional Self- } \\
\text { Regulation Scale } \\
\text { (ESRS) }\end{array}$ & $\begin{array}{ll}\text { - } & \text { Emotional reactivity } \\
\text { management, } \\
\text { - } & \text { emotional stability, } \\
\text { - } & \text { conscientiousness, } \\
\text { - } & \text { achievement drive } \\
\text { - } & \text { Honesty } \\
\text { - } & \text { carefulness } \\
\text { - } & \text { determination } \\
\text { - } & \text { Vision }\end{array}$ & $\begin{array}{l}\text { - Ability to handle emotions in a way that they } \\
\text { don't interfere but facilitate in achieving their } \\
\text { own goals, as well as help their students in } \\
\text { goal achievement. } \\
\text { - Ability to work under pressure and solve } \\
\text { problems } \\
\text { - Ability to translate their preferences into } \\
\text { action to improve and excel. } \\
\text { - They can effectively and constructively } \\
\text { control emotions in challenging and } \\
\text { - } \text { demanding situations } \\
\text { - Flexibility and adaptability towards change }\end{array}$ \\
\hline $\begin{array}{l}\text { Emotional self- } \\
\text { awareness } \\
\text { (ESAS) }\end{array}$ & $\begin{array}{ll}\text { - } & \text { Self-awareness, } \\
\text { - } & \text { emotional knowledge } \\
\text { and it's understanding } \\
\text { - } & \text { self-assessment } \\
\text { - } & \text { Self-confidence }\end{array}$ & $\begin{array}{l}\text { - Conscious of one's emotional strengths and } \\
\text { flaws. } \\
\text { Aware of one's emotions and know-how and } \\
\text { when to react } \\
\text { Ability to be aware of, identify, and } \\
\text { understand their emotions, to identify } \\
\text { numerous feelings, and differentiate between } \\
\text { them. }\end{array}$ \\
\hline $\begin{array}{l}\text { Interpersonal } \\
\text { scale(ISS) }\end{array}$ & 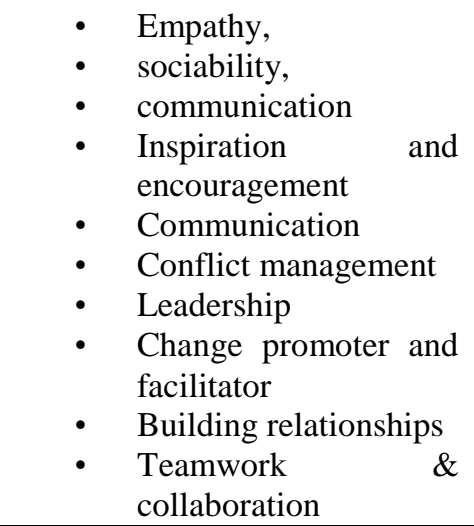 & $\begin{array}{l}\text { - Teachers' ability to establish and maintain } \\
\text { mutually satisfying relationships through trust } \\
\text { and confidence and relate well with others } \\
\text { - Ability to understand and listen to others } \\
\text { - Communicates positively through verbal and } \\
\text { non-verbal mediums } \\
\text { - Have an ability to work in a group and work } \\
\text { for group development }\end{array}$ \\
\hline
\end{tabular}




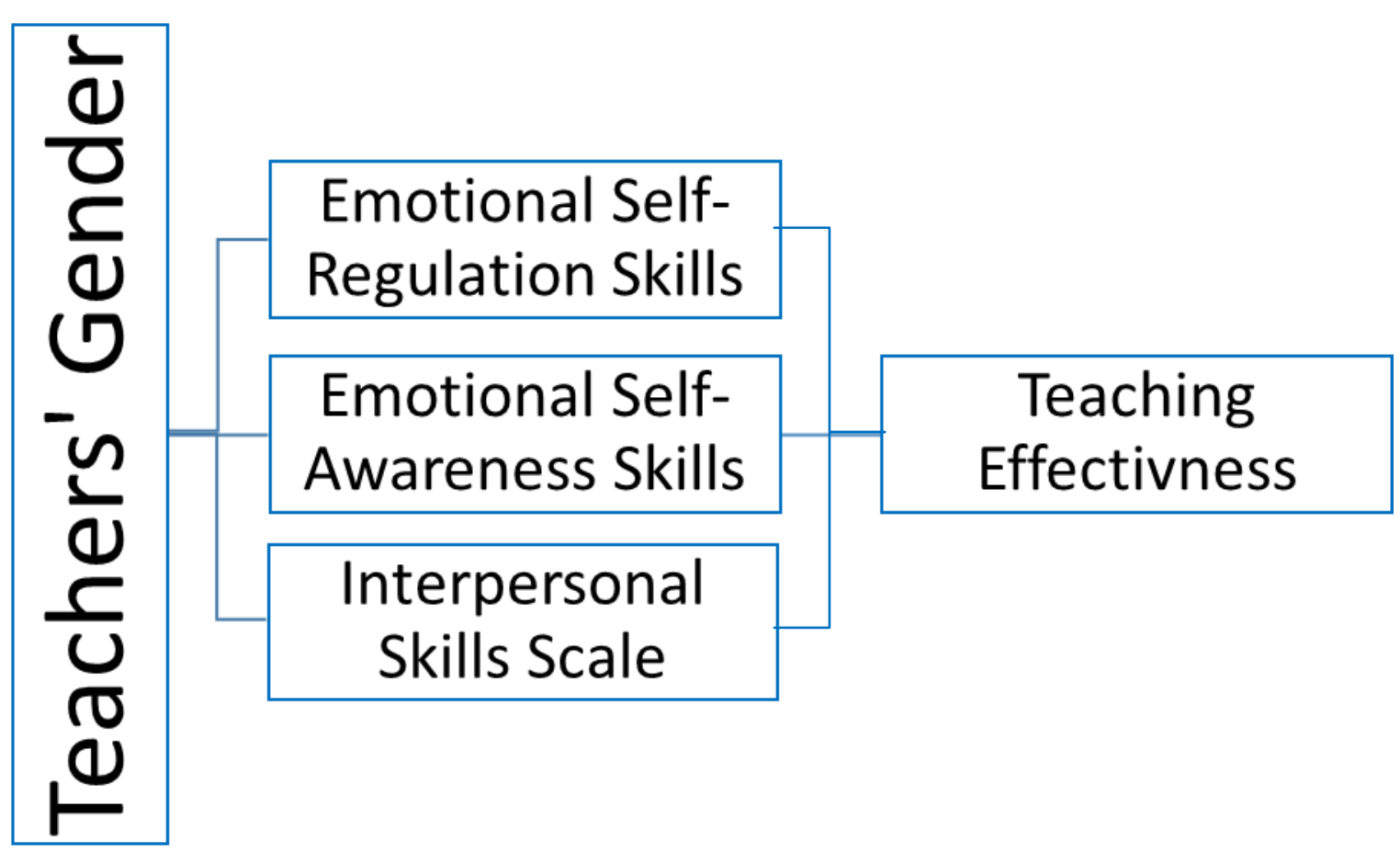

Source: author proposed model

\section{Research Hypothesis}

There is a significant relationship between emotional Self-Regulation skills and teachers' gender.

There is a significant relationship between emotional Self-Awareness and teachers' gender.

There is a significant relationship between Inter-Personal skills and teachers' gender.

\section{Methodology}

Quantitative research approaches are best used in describing current conditions, enquiring about relationships, and investigating cause and effect phenomena (Gay, L. R. et al., 2012). For the research study researcher adopted a quantitative approach to find out the effect of gender on the emotional competencies of teachers.

\section{Sampling}

Quantitative researches generally don't have to gather information from the entire population, if the number of sample of interest is huge or scattered topographically cluster sampling is the best possible technique of obtaining a representative sample (Gay, L. R. et al., 2012). Using cluster sampling technique researcher selected a sample of lecturers from three (03) higher education institutions of Peshawar including the University of Peshawar, Islamia College University of Peshawar, and Agriculture University of Peshawar. Total 290 lecturers are working at these universities, out of which 186 are male lecturers while 104 are female teachers. For the population size of 290, a sample size of one hundred and sixty-five (165) is sufficient to represent the whole population (Krejcie \& Morgan, 1970). Hence sample of 165 teachers were chosen for study purpose using Krejcie and Morgan sample specification table. To guarantee the desired representation of relevant sub-groups i.e. male and female stratified sampling was used. It is the process of selecting a sample that represents the sub-groups of the population in the same proportion in which they exist in the population (Gay, L. R. et al., 2012). Hence researcher utilized stratified proportional sampling for data collection. The researcher collected the data from selected genders i.e. male and female teachers to meet the characteristics required by the present study and selected 106 male and 59 female lecturers from mentioned universities.

\section{Measures}

\section{Demographic datasheet}

The researcher collected demographic information of teachers' names and gender by developing an attached demographic sheet. 


\section{Scale for Measuring Emotional Intelligence of Teachers \\ Self-Report Measure of Emotional Intelligence}

To evaluate lecturers' emotional intelligence, the Researcher adopted the Self-Report Measure of Emotional Intelligence (2010) from the National Institute of Psychology Pakistan. The instrument is comprised of three main facets i.e. emotional self-regulation, emotional self-awareness, and interpersonal skills. It is a 5 point response scale ranging from always to never.

Table 1 Subscales, description, Number of Items of SRMEI (2010)

\begin{tabular}{|c|c|c|}
\hline Sub-scale & Scope & $\begin{array}{l}\text { Total Number of } \\
\text { items }\end{array}$ \\
\hline $\begin{array}{l}\text { Emotional Self-Regulation Scale } \\
\text { (ESRS) }\end{array}$ & $\begin{array}{l}\text { Adaptability, emotional reactivity management, } \\
\text { emotional stability, conscientiousness, } \\
\text { achievement drive }\end{array}$ & 27 \\
\hline $\begin{array}{l}\text { Emotional self-awareness scale } \\
\text { (ESAS) }\end{array}$ & $\begin{array}{l}\text { Self-awareness, perceived self-assessment, } \\
\text { confidence }\end{array}$ & 21 \\
\hline Interpersonal scale(ISS) & Empathy, sociability, communication & 12 \\
\hline
\end{tabular}

Source. Self-report Measure of Emotional Intelligence (2010). Technical Manual. Islamabad Pakistan: National Institute of Psychology.

Table 2 Cronbach's alpha coefficient for SRMEI and its subscale

\begin{tabular}{ll}
\hline Measure & Alpha coefficient \\
\hline Emotional self-regulation scale (ESRS) & .82 \\
Emotional self-awareness scale (ESAS) & .83 \\
Interpersonal skills scale (ISS) & .67 \\
SRMEI (total) & .91 \\
\hline
\end{tabular}

Source: SRMEI (Self-Report Measure of Emotional Intelligence)

Table 3 Potential range of scores on overall SRMEI (2010)

\begin{tabular}{ll}
\hline Range & Guideline \\
\hline 228 and above & Enriched socio-emotional competencies \\
$151-227$ & Satisfactory skills \\
150 and below & Room for improvement \\
\hline
\end{tabular}

Source: SRMEI (Self-Report Measure of Emotional Intelligence)

Table 4 Data Analysis plan

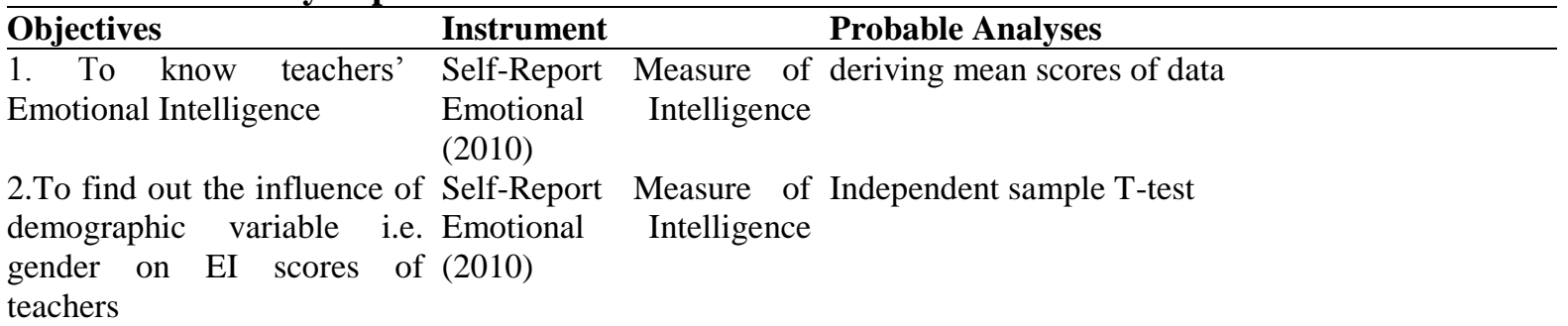

\section{Data Analyses}

The results were evaluated to assess the EI competencies of teachers under three facets i.e. selfawareness skills, self-regulation skills, and interpersonal skills. The researcher used SPSS-20 version software for data analysis. Mean scores of teacher respondents on SRMEI were calculated, while an independent sample t-test was applied to compare the scores of two counter gender groups, whether they are significantly different at the selected probability level.

Table 5 Gender wise comparison of university teachers on Emotional self-regulation scale

\begin{tabular}{lllllll}
\hline & Gender & $\mathrm{N}$ & Mean & Std. Deviation & p-value & t-value \\
\hline \multirow{2}{*}{ ESRS } & Male & 106 & 2.66 & .434 & .178 & -1.348 \\
& Female & 59 & 2.73 & .460 & .189 & -1.318 \\
\hline
\end{tabular}

${ }^{*} \mathrm{p} \leq 0.01$ level (2-tailed)

1. There is a significant relationship between emotional self-regulation skills and teachers' gender.

To determine the relationship between teachers' gender and their emotional self-regulation skills researcher applied an independent sample t-test. Data in the above table show Mean responses on for male respondents on ESRS are $\mathrm{m}=2.66, \mathrm{SD}=.434$, while mean responses on the same facet for female is $\mathrm{m}=2.73, \mathrm{SD}=.460$. For groups to be treated unequally the significant values should be less 
than 0.05. Data did not confirm a relationship between teachers' gender and their emotional selfregulation skills as results revealed that $\mathrm{t}$-value $(-1.34)$ is not significant $(\mathrm{p}=.178)$ for males and $\mathrm{t}$ value $(-1.31)$ is not significant $(\mathrm{p}=.189)$ for female at 0.05 level of significance. Therefore rejecting our hypothesis that teachers' gender has a significant relationship with their emotional self-regulation skills.

Table 6 Gender wise comparison of university teachers on Emotional self-awareness scale

\begin{tabular}{lllllll}
\hline & Gender & $\mathrm{N}$ & Mean & Std. Deviation & $\mathrm{p}$-value & t-value \\
\hline \multirow{2}{*}{ ESAS } & Male & 106 & 2.28 & .552 & .606 & -.516 \\
& Female & 59 & 2.32 & .572 & .612 & -.509 \\
\hline
\end{tabular}

${ }^{*} \mathrm{p} \leq 0.01$ level (2-tailed)

2. There is a significant relationship between emotional self-awareness skills and teachers' gender.

The researcher applied an Independent sample t-test to find out the association between teachers' gender and their emotional self-regulation skills. Data in the above table show Mean responses on the sub-scale of ESAS for male teachers' i.e. $\mathrm{m}=2.28, \mathrm{SD}=.552$, while on the same subscale female mean response is $\mathrm{m}=2.32, \mathrm{SD}=.572$. It was observed that the significance (2-tailed) level was greater than 0.05 and hence the two gender groups were treated as equal. Results discovered that $t$-value ($.516)$ is not significant $(\mathrm{p}=.606)$ for male and $\mathrm{t}$-value $(-.509)$ is not significant $(\mathrm{p}=.612)$ for female at 0.05 level of significance. Hence, rejecting the hypothesis of the research study that there is a significant relationship between teachers' gender and emotional self-awareness skills.

Table 7 Gender wise comparison of university teachers on Interpersonal skill scale

\begin{tabular}{lllllll}
\hline & Gender & $\mathrm{N}$ & Mean & Std. Deviation & p-value & t-value \\
\hline \multirow{2}{*}{ ISS } & Male & 106 & 2.38 & .455 & .000 & -29.67 \\
& Female & 59 & 3.71 & .212 & .000 & -38.04 \\
\hline
\end{tabular}

$* \mathrm{p} \leq 0.01$ level (2-tailed)

3. There is a significant relationship between interpersonal skills and teachers' gender.

An independent sample t-test was applied to establish the relationship between teachers' gender and their emotional self-regulation skills. Data in the above table confirm male teachers mean response on the facet of ISS as $\mathrm{m}=2.38, \mathrm{SD}=.455$, while female teachers mean responses on the same facet is $\mathrm{m}=3.71, \mathrm{SD}=.212$. The significance of the $\mathrm{P}$-value was checked at 0.05 levels and hence the two groups were treated as unequal. Results found that $\mathrm{t}$-value $(-29.6)$ is significant $(\mathrm{p}=.000)$ for male and $\mathrm{t}$-value $(-38.0)$ is significant $(\mathrm{p}=.000)$ for female at 0.05 level of significance. Results inferred showed a statistically significant relationship between teachers' gender Interpersonal Skill Scale. Hence rejecting our hypothesis in light of the findings show that there is a significant relationship between teachers' gender and interpersonal skills.

Results can be depicted in a way that there is a significant relationship between interpersonal skills scale and teachers' gender. On the remaining two components of SRMEI i.e. emotional selfregulation skills and Emotional Self-awareness skills, the researcher doesn't found a substantial connection between teachers' gender and their EI skills.

\section{Conclusion}

Based on the findings of the study, the following conclusions were drawn out:

1. There was no significant difference between the emotional self-regulation skills of male and female university teachers.

2. There was no significant difference between the emotional self-awareness skills of male and female university teachers.

3. Significant difference was found between emotional interpersonal skills of male and female university teachers.

\section{Discussion}

Results of the study indicate that the two genders under study are not very different regarding their overall EI skills; however, an astonishing finding of the study is that female teachers reveal better performance than their counterparts on one of the facets of SRMEI i.e. interpersonal skills. Results of the proposed study publicized that female teachers display better interpersonal skills than male teachers, which is considered as one of the fundamental traits of an effective teacher. They were found in better status to establish and maintain a healthy relationship with their students characterized 
by intimacy and emotional attachment. Female teachers were also found more responsive and approachable by their students. But this could be an effect of our social and cultural values. This difference could be the result of our expectations imposed on different genders by society and the process of socialization (Naghavi \& Redzuan, 2011) as in our society parents have emotional talks more with their daughters and they observed their mothers as caring and nurturing personality (Fivush, 1998; Fivush, Brotman, Buckner, \& Goodman, 2000; Sanches-Nunez, et al., 2008). Brody (1997) was also of the view that different impact of different genders on EI is a result of our socialization process, stigmas related to the role of different genders, and imbalances in power and status of both genders. According to a UNESCO report (2011), in Pakistan females in their very early ages are trained to build tolerance and patience towards all the ills and hurdles of society and manage relationships. Hassan et al., (2015), also found female with effective communication skills, females' productive interaction at their workplaces leading towards success in their profession. The female gender was found to be more kind and empathetic, Zhou, Valiente, and Eisenberg, (2003). Antoniou, Polychroni and Kotroni, (2009) also found female teachers to have more cherished attachment and affection with students. The female gender display better interpersonal relationship than males (Dunn, 2002).

While on the other two components of EI i.e. emotional Self-regulation and emotional Selfawareness both genders scored equally. Both genders don't counter pass each other on the remaining facets of SRMEI skills. Result deduced resemble observations of Goleman (1998), who was of the view that there isn't any difference between the emotional intelligence of both counterparts. He proposed that both gender groups share some similar behavior patterns. Male and female both show certain traits that need not to be ascribed to their gender in particular. Females may be as adaptive and confident as their male counterparts and likewise, males may be as sensitive, communicative, expressive, and empathetic as females. A likely number of studies conducted also unfolds the fact that there isn't any link between EI skills and the gender of teachers. Brackett \& Mayer (2003), also did not found any impact of gender on EI skills. Similarly, studies conducted by Brackett, Rivers, Shiffman, Lerner, and Salovey (2006), didn't reveal any difference between EI skills of both genders. Myint and Aung, (2016) in one of their study found no significant difference between the EI skills of teachers of both genders. The obvious reason could be their existence in the same profession with almost the same academic qualification and their professional lives requires them to be emotionally intelligent equally. The findings of the study are inspiring and cheering for female teachers in higher educational institutions. In a male dominating and patriarchal society like Pakistan, as far as their EI skills are concerned they do not lag behind their male counterparts.

\section{References}

Alnabhan, M. (2008). Assessing the high school teachers' emotional intelligence in Karak district of Jordan. Gifted and Talented International, 23(1), 81-86. Abstract retrieved from http://www.eric.ed.gov/

Arteche, A., Chamorro-Premuzic, T., Furnham, A., \& Crump, J. (2008). The relationship of trait EI with personality, IQ, and sex in a UK sample of employees. International Journal of Selection and Assessment, 16, 421-426.

Antoniou, A.-S., Polychroni, F. \& Vlachakis, A.-S. (2006). Gender and age differences in occupational stress and professional burnout between primary and high-school teachers in Greece Journal of Managerial Psychology,21( 7),682-690.

Anuradha, K. \& Kalapriya, C. (2015), 'Gender and Emotional Intelligence among Adolescents', Indian Journal of Applied Research, Feb, 5(2): 698-699.

Aquino, A. E. (2003). Gender differences and age in a group of web browsers' emotional intelligence (Unpublished thesis). Universidad Inca Graciliazo de la Vega, Lima, Peru.

Bachchan, Mahatma F., Rabindranath, N. L, Azad, \& Srinivasa H. (2016), 'A contrast on the emotional intelligence of adolescent boys' and girls', International Journal of Educational Research and Reviews, Vol. 4 (4): 712-716.

Batool, S., \& Khalid, R. (2011). Development of indigenous scale of emotional intelligence and evaluation of its psychometric properties. Journal of Social and Clinical Psychology, 9, 66-72.

Bay, D., \& McKeage, K. (2006). Emotional intelligence in undergraduate accounting students: Preliminary assessment. Accounting Education, 15(4), 439- 454. DOI: 10.1080/09639280601 01113. 
Bar-On, R. (1997). The Emotional Intelligence Inventory (EQ-i): Technical manual. Toronto, Ontario, Canada: Multi-Health Systems.

Bar-On, R. (2001). Emotional Intelligence and Self Actualization, Emotional Intelligence in Everyday Life: A Scientific Inquiry. New York, Psychology Press.

Bar-On, R. (2000). Emotional and social intelligence: Insights from the Emotional Quotient Inventory (EQ-i). In Bar-On, R., Parker, J. D. A. (Eds.), Handbook of emotional Intelligence (pp. 363388). San Francisco, CA: Jossey-Bass.

Brackett, M. A., Mayer, J.D., \& Warner, R. M. (2004). Emotional intelligence and its relation to everyday behavior. Personality and Individual Differences 36, 1387-1402. Retrieved from www.elsevier.com/locate/paid

Brackett, M. A., Rivers, S. E., Shiffman, S., Lerner, N., \& Salovey, P. (2006). Relating emotional abilities to social functioning: A comparison of self-report and performance measures of emotional intelligence. Journal of Personality and Social Psychology, 91, 780-795.

Brody, L.R. \& Hall, J.A. (2000). Gender, emotion, and expression. In Handbook of Emotions, Ed. by M.Lewis and J.M. Havilland Jones. New York: Guilford

Brody, L. R. (1997). Gender and emotion: Beyond stereotypes. Journal of Social Issues, 53(2), 369393. Doi: 10.1111/0022 4537.00022.

Brown, J. M., \& King, J. (1998). Gender differences in police officers' attitudes towards rape. Psychology, Crime and Law, 4, 265-279.

Brown, R. F., \& Schutte, N. S. (2006). Direct and indirect relationships between emotional intelligence and subjective fatigue in university students. Journal of Psychosomatic Research, 60, 585-593.

Castro-Schilo, L. \& Kee, D. W. (2010). Gender differences in the relationship between emotional intelligence and right hemisphere lateralization for facial processing. Brain and Cognition, 73, 62-67. Retrieved from www.elsevier.com/locate/b\&c

Chandra, A., Gayatri, A., \& Devi, D. (2017). Assessment of emotional intelligence in first-year medical graduates-A Questionnaire-based study. International Journal of Physiology, 5, 124126.

Ciarrochi, J. V., Chan, A.Y.C., \& Caputi, P. (2000). A critical evaluation of the emotional intelligence construct. Personality and Individual Differences, 28, 539-561.

Craig, A., Tran, Y., Hermens, G., Williams, L. M., Kemp, A., Morris, C., \& Gordon, E. (2009). Psychological and neural correlates of emotional intelligence in a large sample of adult males and females. Personality and Individual Differences, 46, 111-115.

Coetzee, M., \& Jansen, C. (2007). Emotional intelligence in the classroom: The secret of happy teachers. South Africa: Juta.

Day, C. \& Qing, G. (2009). Teacher emotions: Wellbeing and effectiveness. In P.A. Schutz \& M. Zembylas (Eds.), Advances in teacher emotion research: The impact on teacher's lives. New York: Springer.

Depape, A. R., Hakim-Larson, J., Voelker, S., Page, S., \& Jackson, D. L. (2006). Self-talk and emotional intelligence in university students. Canadian Journal of Behavioural Science, $38,250-260$.

Domakani, M., Mirzaei, A., \& Zeraatpisheh, S. (2014). L2 learners affect and pragmatic performance: A focus on emotional intelligence and gender dimensions. Journal of Research in Applied Linguistics, 5, 149-174.

Dunn, P. (2002). The impact of starting a new venture on the entrepreneur and their family: Expectation, reality, and willingness to start again. Paper presented at the Association for Small Business and Entrepreneurship Annual Conference, Reno, Nevada.

Dawood, S. (2007). Development of an indigenous scale for emotional intelligence. Pakistan Journal of Psychology, 15-24.

Else-Quest, N. M., Hyde, J. S., Goldsmith, H. H., Van Hulle, C. A. (2006). Gender differences in temperament: A meta-analysis. Psychological Bulletin, 132, 33-72.

Esturgo-Deu, M. E., \& Sala-Roca, J. (2010). Disruptive behavior of students in primary education and emotional intelligence. Teaching and Teacher Education, 26, 830-837. 
Fatt, J. P., \& Howe, C. K. (2003). Emotional intelligence of foreign and local university students in Singapore: Implications for managers. Journal of Business and Psychology, 17(3), 345-367.

Fivush, R. (1998). Methodological challenges in the study of emotional socialization. Psychological Inquiry, 9, 281-283.

Fivush, R., Brotman, M. A., Buckner, J. P., \& Goodman, S. H. (2000). Gender differences in parentchild emotion narratives. Sex Roles, 42, 233-253.

Franke, G., Crown, D., \& Spake, D. (1997). Gender differences in ethical perceptions of business practices: A social role theory perspective. Journal of Applied Psychology, 82, 920-934.

Gay, L. R., Mills, G. E., \& Airasian, P. W. (2012). Educational research: Competencies for analysis and applications. Boston: Pearson.

Goleman, D. (1998). IQ and technical skills are important, but emotional intelligence is the sine qua non of leadership. Harvard business review, 93(1), 93-102.

Gurol, A., Ozercan, M. G., \& Yalçin, H. (2010). A comparative analysis of pre-service teachers' perceptions of self-efficacy and emotional intelligence. Procedia Social and Behavioral Sciences, 2, 3246-3251.

Hassan, F., Chew, B. \& Zain, A.M. \& (2015). The relationship between the social management of emotional intelligence and academic performance among medical students. Psychology, Health \& Medicine, 20(2), 198-204.

Hargreaves, A. (1998). The emotional practice of teaching. Teaching and teacher education, 14(8), 835-854.

Hess, U., \& Thibault, P. (2009). Darwin and emotion expression. American Psychologist, 64(2), 120128.

Harrod, N. R., \& Scheer, S. D. (2005). An exploration of adolescent emotional intelligence in relation to demographic characteristics. Adolescence, 40, 503-512.

Higher Education Commission, (2017). Retrieved from http://hec.gov.pk/Pages/HECMain.aspx

Hourigan, S. E., Goodman, K. L., \& Southam-Gerow, M. A. (2011). Discrepancies in parents' and children's reports of child emotion regulation. Journal of Experimental Child Psychology, 110(2), 198-212.

Kalsoom, S., \& Kamal, A. (2018). Emotional intelligence and multitasking ability predictors of marital adjustment of working married individuals. FWU Journal of Social Sciences, 12(2), 60.

Kar, Dhiman, Saha, Birbal, Mondal \& Bhim Chandra. (2014), Measuring Emotional Intelligence of Secondary School Students in Relation to Gender and Residence: an Empirical Study, American Journal of Educational Research, vol. 2 (4): 193-196.

Krejcie, R.V., \& Morgan, D.W., (1970). Determining Sample Size for Research Activities. Educational and Psychological Measurement.

Kafetsions, K. (2004). Attachment and emotional intelligence abilities across the life course. Personality and Individual Differences, 37, 129-145.

Mayer, J. D., \& Salovey, P. (1997). What is emotional intelligence: In Salovey, \& D. Slutyer (Eds.)? Emotional development and emotional intelligence: Implications for educators, (pp. 3-31). New York: Basic Books.

McIntyre, H. H. (2010). Gender differences in the nature and linkage of higher-order personality factors to trait and ability emotional intelligence. Personality and Individual Differences, 48, 617-622

Krejcie, R.V., \& Morgan, D.W., (1970). Determining Sample Size for Research Activities. Educational and Psychological Measurement.

Mayer, J. D., \& Geher, G. (1996). Emotional intelligence and the identification of emotion. Intelligence, 22, 89-113.

Mortiboys, A. (2013). Teaching with emotional intelligence: A step-by-step guide for higher and further education professionals. London: Routledge.

Montero, I., Aparicio, D., Gómez-Beneyto, M., Moreno-Küstner, B., Reneses, B., Usall, J., \& Vázquez-Barquero, J. L. (2004). Género y salud mental en un mundo cambiante [Gender and Mental Health in a Changing World]. Gac Sanit, 18 (1), 175-181. 
Myint, A. A., \& Aung, A. A. (2016). The relationship between emotional intelligence and job performance of Myanmar school teachers. AsTEN Journal of Teacher Education, 1(1).

Naghavi, F., \& Redzuan, M. (2011). The relationship between gender and emotional intelligence. World Applied Sciences Journal, 15(4), 555-561.

Nasir, M., \& Masrur, R. (2010). An exploration of emotional intelligence of the students of IIUI in relation to gender, age, and academic achievement. Bulletin of Education \& Research, 23, 3751.

Nelson, D.B., Low, G. R., \& Nelson, K. (2005). The Emotionally Intelligent Teacher: A Transformative Learning Model. Retrieved from: http://www.tamuk.edu/edu/kwei000/ research/articles/article_files/emotionally_intelligent-teacher. Pdf on November 11, 1017.

Ngah, R., Jusoff, K., \& Abdul Rahman, Z. (2009). Emotional intelligence of Malaysian academia towards work performance. International Education Studies, 2(2), 103-112. Retrieved from www.ccsenet.org/journal.html

Pakistan Economic Survey. (2011-2012). Retrieved from http://finance.gov.pk/survey/chapters_ 13/10-Education.pdf

Petrides, K. V., \& Furnham, A. (2000). On the dimensional structure of emotional intelligence. Personality and individual differences, 29(2), 313-320.

Parker, J. D., Creque, R. E., Barnhart, D. L., Harris, J. I., Majeski, S. A., Wood, L.M., \& Hogan, M. J. (2004). Academic achievement in high school: does emotional intelligence matter? Personality and Individual Differences, 37(7), 1321-1330.

Perry-Parrish, C., \& Zeman, J. (2011). Relations among sadness regulation, peer acceptance, and social functioning in early adolescence: The role of gender. Social Development, 20, 135-153.

Rastegar, M., \& Memarpour, S. (2009).The relationship between emotional intelligence and selfefficacy among Iranian EFL teachers. System, 37, 700-707.

Sanchez-Nunez, M. T., Fernandez-Berrocal, P., Montanes, J., \& Latorre, J.M. (2008).

Srinivasan, P. "Exploring the influences of teacher's intelligence and emotional intelligence on students' academic achievement." American Journal of Educational Research 3.9 (2015): $1159-1162$.

Rauf, K. (2015). Effect of Birth Order and Gender on Emotional Intelligence of Adolescents. Bahria journal of professional psychology, 14(1).

Ryff, C. D., Singer, B. H., Wing, E., \& Love, G. D. (2001). Elective affinities and uninvited agonies. Emotion, social relationships, and health, 133-75.

Sandhu, P., \& Mehrotra, N. (1999). Time pattern of female students with special reference to leisure time activities. Indian Journal of Social Research, 40(4), 285-296.

Sanchez-Nunez, M., Fernández-Berrocal, P., Montañés, J., \& Latorre, J. M. (2008). Does emotional intelligence depend on gender? The socialization of emotional competencies in men and women and its implications.

Stein, S., Book, H., \& Kanoy, K. (2013). The student EQ edge: Emotional intelligence and your academic and personal success. San Francisco, CA: Jossey-Bass.

Sutton, R. E., \& Wheatley, K. F. (2003). Teachers' emotions and teaching: A review of the literature and directions for future research. Educational psychology review, 15(4), 327-358.

Sanchez-Nunez, M. T., Fernández-Berrocal, P., Montanes, J., \& Lattore, J. M. (2008). Does emotional intelligence depend on gender? The socialization of emotional intelligence in males and females and its implications. Electronic Journal of Research in Educational Psychology, $6,455-474$.

Siegling, A. B., Furnham, A., \& Petrides, K. V. (2015). Trait emotional intelligence and personality: Gender-invariant linkages across different measures of the Big Five. Journal of psychoeducational assessment, 33(1), 57-67.

SRMEI. (2010). Self-report Measure of Emotional Intelligence (2010). Technical Manual. Islamabad Pakistan: National Institute of Psychology.

Thorndike, E. L. (1920). Intelligence and its uses. Harper's Magazine, 140, 227-235. Retrieved from https://harpers.org/archive/1920/01/intelligence-and-its-uses/, on January 1, 2018.

Tiwari, P. S. N. and Srivastava, N. (2004), 'Schooling and Development of Emotional Intelligence', Psychological Studies, 49, 151-154. 
UNESCO. (2011). Women and the teaching profession: Exploring the feminization debate. London: Commonwealth Secretariat UNESCO.

Van Rooy, D. L., Alonso, A., \& Viswesvaran, C. (2005). Group differences in emotional intelligence test scores: Theoretical and practical implications. Personality and Individual Differences, $38,689-700$.

Von Stumm, S., Hell, B., \& Chamorro-Premuzic, T. (2011). The hungry mind: Intellectual curiosity is the third pillar of academic performance. Perspectives on Psychological Science, 6(6), 574588.

Viin, T., Juust, L., \& Tooman, H. (2010). Emotional intelligence of teachers of tourism and hospitality students: the case of Estonia. Retrieved from http://eurochrie2010.nl/ publications/103.pdf

Wessell, J., Larin, H., Benson, G., Brown, B., Pleog, J., Williams, R., \& Martin, L. (2008). Emotional- social intelligence in health science students and its relationship to leadership, caring, and moral judgments. The International Journal of Allied Health Sciences and Practice, 6(1), 1-9. Retrieved from http://ijahsp.nova.edu

Wong, C. S., Law, K. S. (2002). The effects of leader and follower emotional intelligence on performance and attitude: An exploratory study. The Leadership Quarterly, 13, 243-274.

Zhou, Q., Eisenberg, N., Wang, Y., \& Reiser, M. (2004). Chinese children's effortful control and dispositional anger/frustration: Relations to parenting styles and children's social functioning. Developmental Psychology, 40, 352-366. 